\title{
Př́ijem bílkovin po odporovém tréninku a svalová hypertrofie (přehledová práce)
}

\section{Protein Intake in Post-Resistance Exercise Period and Muscle Hypertrophy}

\author{
Michal Richter, Michal Kumstát \\ Fakulta sportovních studií Masarykovy univerzity v Brně
}

\begin{abstract}
Abstrakt
Př́jem bilkovin a odporový trénink jsou faktory ovlivňující míru svalové proteosyntézy. Jedním z adaptačních projevů je svalová hypertrofie jako důsledek pozitivní bílkovinné bilance mezi mírou svalové proteosyntézy a svalové proteolýzy. Príijem bilkovin s obsahem esenciálních aminokyselin v období po zatížení je nutným predpokladem účinné adaptace. Postprandiální vzestup aminoacidémie je stěžejním faktorem efektivity proteosyntetických dějů. Mezi nejpoužívanější druhy bílkovin uplatňované ve sportovní výživě patři mléčné bílkoviny, vaječná a sójová bílkovina. Existují mezi nimi značné rozdily v digesci a kinetice resorbovaných esenciálních aminokyselin. Syrovátková bílkovina je pro svůj obsah esenciálních aminokyselin a zastoupení leucinu nadřazená ostatním bílkovinným zdrojüm a je považována za významný anabolický stimulus. Jednorázové množství 20-25 g syrovátkové bílkoviny zkonzumované po skončení zatižení optimalizuje podmínky pro svalovou hypertrofii. Vhodné načasování príjmu bilkovin do těsné blizkosti zatížení pozitivně ovlivňuje snahu sportovce dosáhnout svalové hypertrofie.
\end{abstract}

\begin{abstract}
Protein intake and resistance training are factors affecting the rate of muscle protein synthesis. Muscle hypertrophy manifests as a result of a positive protein balance between the rate of muscle protein synthesis and muscle protein breakdown. An intake of protein containing essential amino acids in the period after the resistance exercise is a key prerequisite of an effective adaptation. Postprandial hyperaminoacidemia is a key factor in the effectiveness of proteosynthetic processes. The most common types of protein used in sports nutrition include milk protein, egg and soy protein. There are significant differences among them in the context of digestion and essential amino acids resorptio kinetics. Whey protein represents due to the high content of essential amino acids and leucine a superior source and is considered an important anabolic stimuli. An amount of $\sim 20-25 \mathrm{~g}$ of whey protein consumed after restistance exercise optimizes conditions for muscle hypertrophy. Appropriate timing of protein intake in close proximity to the load positively affects an athletes attempt to achieve muscle hypertrophy.
\end{abstract}

Klíčová slova: svalová proteosyntéza, syrovátka, aminokyseliny, leucin.

Key words: muscle proteosynthesis; whey protein; aminoacids; leucin.

\section{ÚVOD}

Dosažení svalové hypertrofie patři mezi cíle silově zaměřených sportovců. Jedná se o složitý proces ovlivňovaný mnoha faktory, ovlivnitelnými i neovlivnitelnými. Mezi neovlivnitelné interindividuální charakteristiky patř́ např. věk, pohlaví, fyziologické hladiny důležitých hormonů nebo genetika. Přítomnost pohybové aktivity odporového charakteru a odpovídající výživové chování sportovce jsou naopak faktory ovlivnitelné, které jsou v úzké synergicky působící vazbě. Je prokázáno, že odporový trénink je významným činitelem podpory hypertrofie svalové tkáně (Schoenfeld, 2010). Př́ijem bílkovin ve správném množství a ve správném čase efekt svalové hypertrofie 
podporuje (Moore et al., 2009a). Svalová hypertrofie je podmíněna stavem pozitivní bílkovinné bilance ve svalu. Tato bilance je určena vztahem mezi syntézou a degradací bílkovin a podléhá akutnímu i chronickému vlivu př́ijmu bílkovin a fyzické zátěže (Phillips, Tipton, Aarsland, Wolf, \& Wolfe, 1997). Sportovec může vhodnou dietní či tréninkovou strategií pozitivně ovlivnit míru syntézy bílkovin, zajistit pozitivní bílkovinnou bilanci a přispět ke svalové hypertrofii.

Je známo, že cvičení zvyšuje nároky na množství bílkovin v dietě (Lemon, 1998)carbohydrate availability, exercise type, energy balance, gender, exercise training, age, and timing of nutrient intake or subsequent exercise sessions. Dle současných doporučení by měly být bílkoviny ve výživě sportovce přijímány v množství 1,2-1,8 g/kg tělesné hmotnosti (Phillips \& Van Loon, 2011). Současné poznatky sportovce nutí zajímat se nejen o absolutní množství zkonzumovaných bílkovin za den, ale především o jejich zdroj, skladbu zastoupených aminokyselin, jednorázově podané množství, a to vše $v$ př́mé vazbě na odporový trénink (tzv. načasování př́ijmu). Cílem sdělení je na základě rešerše současných zahraničních pramenů prezentovat roli bílkovin v kombinaci s odporovým tréninkem jako klíčového činitele svalové hypertrofie.

\section{Svalová hypertrofie}

Svalová hypertrofie neboli zvětšení př́icného průřezu svalového vlákna je přirozený adaptační fyziologický proces doprovázený změnami jak na buněčné, tak i mimobuněčné úrovni. Z těchto změn můžeme jmenovat např́íklad zvětšení objemu sarkoplasmy, novotvorbu nebo zvětšení objemu kontraktilních proteinů aktinu a myosinu, či v neposlední řadě syntézu nekontraktilních pojivových tkání (Schoenfeld, 2010). Z hlediska hypertrofické odpovědi různých typů svalových vláken je pozorována největší citlivost vưči odporovému tréninku u vláken II. typu (Deschenes \& Kraemer, 2002).

Rozlišit můžeme dva druhy svalové hypertrofie - sarkoplasmatickou a myofibrilární. Sarkoplasmatická hypertrofie je charakterizována nárůstem objemu sarkoplasmy a nekontraktilních bílkovin. Hustota myofibril se ve svalovém vláknu snižuje, naproti tomu se zvětšuje jeho průřez bez odpovídajícího zvětšení svalové síly. Při myofibrilární hypertrofii dochází ke zvětšování myofibril uložených ve svalovém vlákně. Objem svalového vlákna se mění úměrně zvětšení průřrezu myofibril. Dochází také k syntéze kontraktilních bílkovin aktinu a myosinu (Zatsiorsky \& Kraemer, 2006).

Sarkoplasmatická hypertrofie je některými autory označována za nefunkční, nebot nevede k rozvoji silových schopností. Myofibrilární je naopak označována jako za funkční (Thibaudeau, 2007).

Odporový trénink významně stimuluje především syntézu myofibrilárních frakcí bílkovin, kdežto vytrvalostní typ zátěže má větší vliv na tvorbu frakcí mitochondriálních (Wilkinson et al., 2008).

Odporový trénink v kombinaci s příjmem bílkovin syntézu myofibrilárních bílkovin stimulují synergicky a jsou klíčovým anabolickým stimulem svalové hypertrofie (Moore et al., 2009).

Z nutričního hlediska je svalová hypertrofie podmíněna bilancí bílkovin, která vede $\mathrm{k}$ dlouhodobé dominanci svalové proteosyntézy (MPS) ${ }^{1}$ nad svalovou proteolýzou (degradací svalových bílkovin, MPB) $)^{2}$.

Proteosyntéza je proces představující novotvorbu bílkovin. Jde o komplikovaný několikastupňový proces, který započne $\mathrm{v}$ momentě, kdy organismus dostane určitý podnět k jeho spuštění. Tímto podnětem může být například prŕjem specifických živin, hormonální aktivita, svalová práce či energetický stav buňky daný aktivitou AMP-kinázy a dalších enzymů či metabolických drah (Kittnar \& Mlček, 2009).

Proces degradace kompletních bílkovin na jejich jednodušší složky (aminokyseliny či peptidové řetězce) označujeme jako proteolýza. Ke svalové proteolýze může docházet v postresorpčním období metabolismu, u patologických stavů (infekce, trauma, popáleniny...), hladovění nebo

\footnotetext{
${ }^{1}$ MPS; $\mathrm{z}$ angl. muscle protein synthesis

${ }^{2}$ MPB; z angl. muscle protein breakdown
} 
v důsledku fyzické zátěže. Ve sportu je proces proteolýzy spojený hlavně s katabolismem bílkovin kosterního svalstva.

Snaha o novotvorbu svalových bílkovin by neměla být stěžejní strategií sportovce ve snaze dosáhnout hypertrofie zatěžovaných svalů. Sportovci lpí na maximální stimulaci MPS, ačkoliv k dosažení pozitivní bílkovinné bilance může dojít i prostou redukcí MPB bez výrazných proteosyntetických změn (Burke \& Deakin, 2009).

Z metodologického hlediska jsou akutní pozátěžové projevy pozorované ve svalové tkáni po př́ijmu živin, jako jsou zvýšená MPS, genová exprese atd., odbornou literaturou konzistentně považovány za indikátory dlouhodobé svalové adaptace. V případě, že je podnět (tréninkové zatížení a př́jem bílkovin) dlouhodobý, opakovaný a nepřerušovaný, projeví se jmenované akutní krátkodobé změny svalovou hypertrofií. Recentní práce Mitchella et al. (2014) však s touto tezí polemizuje. Podle autorů akutní (1-6 h) pozátěžová proteosyntetická odpověd' nekoreluje se svalovou hypertrofií indukovanou 16týdenním odporovým tréninkem. Autoři naznačují, že měřítko svalové proteosyntézy jako okamžité odpovědi organismu není dostatečným prediktivním nástrojem svalové hypertrofie. K odhalení interindividuálního hypertrofického potenciálu jsou podle autorů nutné další informace z oblastí proteomiky ${ }^{3}$, genomiky ${ }^{4}$ a transkriptomiky ${ }^{5}$.

\section{Př́ijem bílkovin a aminokyselin}

Množství, zdroj, načasování př́ijmu či způsob dávkování bílkovin jsou důležité aspekty ovlivňující proteosyntetické děje (Campbell et al., 2007). Kličovou roli hrají nejen samotné bílkoviny, ale především zastoupené aminokyseliny (Hulmi, Lockwood, \& Stout, 2010). Podle současných poznatků esenciální a neesenciální aminokyseliny působí na úroveň svalové proteosyntézy rozdílně. Výsledky studií jasně ukazují, že rozhodující roli při stimulaci MPS hrají esenciální aminokyseliny. Při podání neesenciálních aminokyselin je vliv na svalovou proteosyntézu redukovaný, ve srovnání s isoenergetickým a isonitrogenním množstvím esenciálních aminokyselin (Tipton, Ferrando, Phillips, Doyle, \& Wolfe, 1999).

Za nejdůležitější aminokyselinu se v oblasti ovlivnění míry MPS považuje leucin (Norton \& Layman, 2006; Koopman et al., 2005). Je považován za kritického činitele ovlivňujícího translační pochody proteosyntézy. Biochemické působení leucinu na buněčné úrovni se připisuje anabolicky působící mTOR signální dráze. Leucin dokáže nezávisle na jiných činitelích stimulovat svalovou proteosyntézu mTOR signální kaskádou (Norton et al., 2009). Proteinkináza mTOR dále působí na tzv. iniciační faktory, např́klad eIF4E či $\mathrm{p} 70^{\mathrm{s} 6} \mathrm{~K}$, které jsou zodpovědné za translaci genetické informace při proteosyntéze. Ze studií na zvířecích modelech je možné usoudit, že obsah leucinu v jakémkoliv jídle obsahujícím bílkoviny je limitujícím faktorem úrovně svalové proteosyntézy (Norton, Wilson, Layman, Moulton, \& Garlick, 2012).

\section{Dietní zdroje bílkovin}

Z nutričního hlediska ovlivňují MPS především konzumované bílkoviny, $\mathrm{v}$ nich zastoupené esenciální aminokyseliny, a především koncentrace leucinu. To je jeden ze zásadních faktorů, který odlišuje pozorovaný výsledný efekt různých zdrojů bílkovin (Tang \& Phillips, 2009)whey hydrolysate and soy. V odborné literatuře i běžné praxi se nejčastěji používají mléčné (syrovátková a kaseinová frakce) a sójové bílkoviny.

Hartman et al. (2007) srovnával vliv konzumace nízkotučného mléka, sójového proteinu (izokalorický, izonitrogenní a izomakroživinový roztok jako mléko) a maltodextrinu (izokalorické množství). Konzumenti mléka ( 17 g B, 1 h po odporové zátěži) v porovnání s ostatními jedinci dosáhli významně větších hypertrofických změn svalových vláken I. a II. typu. Existuje jedno-

\footnotetext{
${ }^{3}$ Vědní disciplína zabývající se proteomem, a studující strukturu a interakce proteinů.

${ }^{4}$ Podobor genetiky zabývající se studiem genomu jednotlivých organizmů.

${ }^{5}$ Vědní obor stanovující soubor mRNA transkriptů v určitém typu buněk a změny exprese genů vyvolávané chorobami.
} 
značná evidence, že konzumací samotného mléka po odporovém tréninku významně podpoříme svalovou proteosyntézu. Pozitivní vliv př́tomné syrovátkové a kaseinové bílkoviny na MPS či jiné důležité indikátory předpokládající svalový anabolismus dokazuje mnoho odborných prací (Elliot, Cree, Sanford, Wolfe, \& Tipton, 2006).

Výsledky studií jsou konzistentní ve tvrzení, že z hlediska efektivní stimulace proteosyntézy je klíčovým faktorem kinetika vzestupu aminoacidémie v krevním řečišti (West et al., 2011). Podle Bohé, Low, Wolfe, \& Rennie (2003) existuje pozitivní závislost mezi extracelulární koncentrací aminokyselin a mírou svalové proteosyntézy. Intracelulární koncentrace aminokyselin míru proteosyntézy neovlivňuje.

Mléko se skládá ze dvou proteinových frakcí - syrovátky (20\%) a kaseinu (80 \%). Z důvodu rychlejšího trávení, resorpční kinetiky a vyššímu obsah leucinu je syrovátková frakce nadřazená kaseinové mléčné frakci (Pennings et al., 2011).

Změny na úrovni arteriovenózní a buněčné bilance vybraných esenciálních aminokyselin (leucin, fenylalanin) po konzumaci frakcí mléčných bílkovin v kombinaci s odporovým tréninkem sledoval jako první Tipton et al. (2004). Jednu hodinu po absolvování indikované zátěže byl účastníkům placebem kontrolované studie ( $\mathrm{n}=23$, muži) podán roztok s obsahem $20 \mathrm{~g}$ kaseinu nebo syrovátky. Plasmatické hladiny leucinu byly po podání syrovátky signifikantně zvýšené po dobu 4 h po skončení zatížení. Pozitivní bílkovinná bilance vedoucí k nárůstu proteosyntézy v čase 5 h po zatížení byla v obou prrípadech shodná a mezi syrovátkou a kaseinem nebyly shledány statisticky významné odlišnosti.

Již roku 1997 Boirie et al. zjistili, že přitomnost odporového tréninku má zřejmý modulující vliv na kinetiku vstřebaných aminokyselin a následné reakce organismu po podaní bílkovin. Dokumentuje to i recentní práce Tanga et al. (2009a)whey hydrolysate and soy, který sledoval rozdíly v MPS po podání $21 \mathrm{~g}$ syrovátkové, sójové nebo kaseinové bílkoviny (s obsahem $10 \mathrm{~g}$ esenciálních aminokyselin) v kombinaci s odporovým zatížením nebo v jeho nepřítomnosti. Vliv syrovátkového hydrolyzátu na míru svalové proteosyntézy v klidu (bez předchozího zatížení) byl ve srovnání se sójovým izolátem a kaseinovým hydrolyzátem signifikantně vyšší. Tento efekt byl dále potencován při administraci bílkoviny po odporové zátěži. Jednou z prríčin může být pozorovaná signifikantně zvýšená plasmatická koncentrace esenciálních aminokyselin a leucinu v době 30-60 minut po podání syrovátky ve srovnání se sójou a kaseinem.

\section{Množství konzumovaných bílkovin}

Jak již bylo uvedeno, změna v úrovni svalové proteosyntézy je v přimé úměře vůči množství přijímaných esenciálních aminokyselin. Klíčový výzkum odhalující vztah mezi množstvím přijatých bílkovin a mírou proteosyntézy ve svalové tkáni po zatížení provedli Moore et al. (2009a). Byla potvrzena stoupající tendence MPS v čase 4 h po zatížení přímo úměrně zvyšujícímu se množství konzumovaných bílkovin $(0,5,10,20,40 \mathrm{~g}$ bílkovin). Př́jem $40 \mathrm{~g}$ vaječné bílkoviny v porovnání s $20 \mathrm{~g}$ ( 8,6 g esenciálních aminokyselin) vedl k signifikantně vyšší oxidaci leucinu. Frakční syntéza svalových bílkovin dosáhla plató hranice v množství $20 \mathrm{~g}$. Na základě uvedené studie se za optimální množství jednorázově zkonzumovaných plnohodnotných bílkovin se zastoupením esenciálních aminokyselin považuje $20-25$ g. Toto zjištění bylo dále podrobeno studiu vhodné distribuce př́ijmu bílkovin v čase po zatížení (Areta et al., 2013). V unikátním experimentu byl sledován vliv třech odlišných strategií distribuce bílkovin podaných v průběhu 12 hodin po odporovém cvičení (pulsní př́ijem $8 \times 10$ g každých 90 minut, nebo bolusový $4 \times 20$ g každé třì hodiny a $2 \times 40$ g každých 6 hodin). Bolusové dávkování v množství $4 \times 20 \mathrm{~g}$ maximalizovalo syntézu myofibrilárních bílkovin. Strategie pravidelného dávkování množství bílkovin minimalizuje exogenní oxidaci aminokyselin (ztráty), a naopak maximalizuje jejich vliv na MPS.

Problematika vhodného načasování příjmu živin je ve sportovní výživě klíčovým faktorem regenerace a žádoucí adaptace organismu po absolvovaném zatížení (Kerksick et al., 2008). Na danou oblast je možné se dívat jak z hlediska akutního (vázán na předtréninkovou a potréninkovou 
dobu), tak i z aspektu chronického (časování př́ijmu živin během celého dne), nebo z pohledu tréninkového (trénovanost).

\section{Načasování př́ijmu bílkovin}

Jeden z prvních experimentů, s cílem zjistit v jakém čase po skončení oporového tréninku př́jem bílkovin optimalizuje podmínky pro svalovou hypertrofii, provedli Rasmussen, Tipton, Miller, Wolf, \& Wolfe (2000). Zjistili, že svalová proteosyntéza se po př́ijmu esenciálních aminokyselin $(6 \mathrm{~g})$ v kombinaci se $35 \mathrm{~g}$ sacharózy při konzumaci $1 \mathrm{~h}$ nebo $3 \mathrm{~h}$ po skončení zatížení nemění. Teorii nutnosti okamžitého přijmu bílkovin, resp. aminokyselin tak autoři nepotvrzují.

Naopak Esmarck et al. (2001) u starších jedinců prokázal, že př́ijem obdobného množství aminokyselin (podáno $10 \mathrm{~g}$ bílkovin) ihned po ukončení tréninku stimuluje svalovou hypertrofii více než konzumace bílkovin s dvouhodinovým zpožděním. Svalová hypertrofie byla analyzována biopticky. Vysvětlením může být snížená sensitivita starších jedinců na př́jem bílkovin, resp. aminokyselin, později popsaná mnoha autory. U starších jedinců je k ekvivalentní proteosyntetické odpovědi organismu nezbytné větší množství bílkovin ( 25-40g) (Breen \& Phillips, 2011).

Důležitost načasování konzumace živin potvrzuje i recentní výzkum Mori (2014), který sledoval akutní vliv př́ijmu bílkovin $(0,3 \mathrm{~g} / \mathrm{kg}) \mathrm{v}$ čase ihned po skončení tréninku nebo s odstupem 6 h na dusíkovou bilanci u trénovaných a netrénovaných jedinců. Ukázalo se, že konzumace bílkovin ihned po zátěži je významným prediktorem k dosažení pozitivní dusíkové bilance, ale pouze u trénovaných jedinců. U netrénovaných jedinců nebyly registrovány signifikantní změny.

Tipton et al. (2001) ve snaze odhalit, zda je př́jem bílkovin před tréninkem významnější než období po tréninku, podával kombinaci sacharidů a esenciálních aminokyselin ( $6 \mathrm{~g})$. Autoři shledali předtréninkový příjem živin jako signifikantně výhodnější.

Tuto tezi kladného efektu předtréninkového přijmu živin později stejný autor vyvrací (Tipton et al., 2007). Mezi př́jmem $20 \mathrm{~g}$ bílkovin před nebo $1 \mathrm{~h}$ po tréninku nebyl v př́ípadě MPS pozorován žádný rozdíl.

Recentní práce Fujity et al. (2009) naopak tvrdí, že př́ijem bílkovin (esenciální aminokyseliny zastoupené $\mathrm{v}$ množství $0,35 \mathrm{~g} / \mathrm{kg}$ beztukové tělesné hmoty) v čase $1 \mathrm{~h}$ po zátěži je optimální strategií zvyšující míru MPS v tomto období.

Př́ijem živin v těsné blízkosti tréninku, přes opakované inkonsistentní závěry experimentů poslední dekády, nadále zůstává jednoznačnou podmínkou efektivní svalové hypertrofie (Cribb \& Hayes, 2006). Autoři ve své longitudinální studii demonstrovali, že př́jem směsi sacharidů, bílkovin a kreatinu bezprostředně před a ihned po ukončení odporové zátěže vede k signifikantním změnám antropometrických parametrů ve srovnání s isoenergetickým a isonitrogenním množstvím bílkovin konzumovaných mimo časovou blízkost odporového tréninku.

\section{ZÁVĚR}

Výživa a odporový trénink jsou dominantními činiteli ovlivňující svalovou proteosyntézu. Svalová proteosyntéza indukovaná odporovým tréninkem je dále potencována př́ijmem bílkovin. Synergický vztah mezi zatížením a potréninkovým př́ijmem bílkovin zajištuje optimální podmínky pro svalovou hypertrofii. Odporová zátěž stimuluje zejména syntézu myofibrilárních a sarkoplazmatických bílkovin.

Svalová proteosyntéza je podmíněna př́ijmem esenciálních aminokyselin. Optimální množství esenciálních aminokyselin k podpoře svalové proteosyntézy se pohybuje v rozmezí 8-10 g v jedné dávce podané po zatížení. Nejvýznamnější vliv na svalovou proteosyntézu je ze všech esenciálních aminokyselin pozorován zejména u leucinu. Kombinace esenciálních aminokyselin a sacharidů nevede $\mathrm{k}$ vyšší hladině proteosyntézy, než je sledováno po podání samotných aminokyselin. Nicméně prríjem sacharidů po zatížení přispívá k čisté proteinové bilanci prostřednictvím snížení degradace svalových bílkovin. Syrovátková bílkovina je vzhledem k obsahu esenciálních aminokyselin a vysokému zastoupení leucinu nadřazena ostatním zdrojům. 
Optimální jednorázově podané množství bílkovin je determinováno věkem a trénovaností jedince. Míra proteosyntézy u starších nebo trénovaných jedinců v porovnání s jedinci mladšími a netrénovanými je po podání stejného množství bílkovin významně redukovaná. Množství bílkovin maximalizující svalovou proteosyntézu u mladších jedinců je 20-25 g, respektive 25-40 g u jedinců staršího věku.

Pravidelný př́ijem plnohodnotných bílkovin s obsahem esenciálních aminokyselin rozdělený do 4-5 jídel v jednorázovém množství $15-25 \mathrm{~g}$ v průběhu tréninkového dne vytváŕí nejpř́iznivější podmínky pro svalovou hypertrofii prostřednictvím dostatečné stimulace svalové proteosyntézy.

\section{Seznam literatury}

Areta, J. L., Burke, L. M., Ross, M. L., Camera, D. M., West, D. W. D., Broad, E. M., ... Coffey, V. G. (2013). Timing and distribution of protein ingestion during prolonged recovery from resistance exercise alters myofibrillar protein synthesis. The Journal of Physiology, 591(Pt 9), 2319-2331. http://doi.org/10.1113/jphysiol.2012.244897

Bohé, J., Low, A., Wolfe, R. R., \& Rennie, M. J. (2003). Human Muscle Protein Synthesis is Modulated by Extracellular, Not Intramuscular Amino Acid Availability: A Dose-Response Study. The Journal of Physiology, 552(1), 315-324. http://doi. org/10.1113/jphysiol.2003.050674

Boirie, Y., Dangin, M., Gachon, P., Vasson, M.-P., Maubois, J.-L., \& Beaufrère, B. (1997). Slow and fast dietary proteins differently modulate postprandial protein accretion. Proceedings of the National Academy of Sciences, 94(26), 14930-14935.

Breen, L., \& Phillips, S. M. (2011). Skeletal muscle protein metabolism in the elderly: Interventions to counteract the „anabolic resistance" of ageing. Nutrition \& Metabolism, 8, 68. http://doi.org/10.1186/1743-7075-8-68

Burke, L., \& Deakin, V. (2009). Clinical Sports Nutrition, 4th Edition (4 edition). Sydney: McGraw-Hill Book Company Australia.

Campbell, B., Kreider, R. B., Ziegenfuss, T., La Bounty, P., Roberts, M., Burke, D., ... Antonio, J. (2007). International Society of Sports Nutrition position stand: protein and exercise. Dostupné $\mathrm{z}$ http://www.jissn.com/content/4/1/8

Cribb, P. J., \& Hayes, A. (2006). Effects of supplement timing and resistance exercise on skeletal muscle hypertrophy. Medicine and Science in Sports and Exercise, 38(11), 1918-1925. http://doi.org/10.1249/01.mss.0000233790.08788.3e

Deschenes, M. R., \& Kraemer, W. J. (2002). Performance and physiologic adaptations to resistance training. American Journal of Physical Medicine \& Rehabilitation / Association of Academic Physiatrists, 81(11 Suppl), S3-16. http://doi. org/10.1097/01.PHM.0000029722.06777.E9

Elliot, T. A., Cree, M. G., Sanford, A. P., Wolfe, R. R., \&Tipton, K. D. (2006). Milk ingestion stimulates net muscle protein synthesis following resistance exercise. Medicine and Science in Sports and Exercise, 38(4), 667-674. http://doi.org/10.1249/01. mss.0000210190.64458.25

Esmarck, B., Andersen, J. L., Olsen, S., Richter, E. A., Mizuno, M., \& Kjaer, M. (2001).Timing of postexercise protein intake is important for muscle hypertrophy with resistance training in elderly humans. The Journal of Physiology, 535(Pt 1), 301-311.

Fujita, S., Dreyer, H. C., Drummond, M. J., Glynn, E. L., Volpi, E., \& Rasmussen, B. B. (2009). Essential amino acid and carbohydrate ingestion before resistance exercise does not enhance postexercise muscle protein synthesis. Journal of Applied Physiology, 106(5), 1730-1739. http://doi.org/10.1152/japplphysiol.90395.2008

Hartman, J. W., Tang, J. E., Wilkinson, S. B., Tarnopolsky, M. A., Lawrence, R. L., Fullerton, A. V., \& Phillips, S. M. (2007). Consumption of fat-free fluid milk after resistance exercise promotes greater lean mass accretion than does consumption of soy or carbohydrate in young, novice, male weightlifters. American Journal of Clinical Nutrition, 86(2), 373-381.

Hulmi, J. J., Lockwood, C. M., \& Stout, J. R. (2010). Effect of protein/essential amino acids and resistance training on skeletal muscle hypertrophy: A case for whey protein. Nutrition \& Metabolism, 7, 51. http://doi.org/10.1186/1743-7075-7-51

Kerksick, C., Harvey, T., Stout, J., Campbell, B., Wilborn, C., Kreider, R., ... Antonio, J. (2008). International Society of Sports Nutrition position stand: Nutrient timing. Journal of the International Society of Sports Nutrition, 5(1), 17. http://doi. org/10.1186/1550-2783-5-17

Kittnar, O., \& Mlček, M. (2009). Atlas fyziologických regulací. Grada Publishing a.s.

Koopman, R., Wagenmakers, A. J. M., Manders, R. J. F., Zorenc, A. H. G., Senden, J. M. G., Gorselink, M., ... van Loon, L. J. C. (2005). Combined ingestion of protein and free leucine with carbohydrate increases postexercise muscle protein synthesis in vivo in male subjects. American Journal of Physiology. Endocrinology and Metabolism, 288(4), E645-653. http://doi.org/10.1152/ajpendo.00413.2004

Lemon, P.W. (1998). Effects of exercise on dietary protein requirements. International Journal of Sport Nutrition, 8(4), $426-447$.

Mitchell, C. J., Churchward-Venne, T. A., Parise, G., Bellamy, L., Baker, S. K., Smith, K., ... Phillips, S. M. (2014). Acute postexercise myofibrillar protein synthesis is not correlated with resistance training-induced muscle hypertrophy in young men. PloS One, 9(2), e89431. http://doi.org/10.1371/journal.pone.0089431

Moore, D. R., Robinson, M. J., Fry, J. L., Tang, J. E., Glover, E. I., Wilkinson, S. B., ... Phillips, S. M. (2009a). Ingested protein dose response of muscle and albumin protein synthesis after resistance exercise in young men. The American Journal of Clinical Nutrition, 89(1), 161-168. http://doi.org/10.3945/ajcn.2008.26401

Moore, D. R., Tang, J. E., Burd, N. A., Rerecich, T., Tarnopolsky, M. A., \& Phillips, S. M. (2009). Differential stimulation of myofibrillar and sarcoplasmic protein synthesis with protein ingestion at rest and after resistance exercise. The Journal of Physiology, 587(4), 897-904. http://doi.org/10.1113/jphysiol.2008.164087 
Mori, H. (2014). Effect of timing of protein and carbohydrate intake after resistance exercise on nitrogen balance in trained and untrained young men. Journal of Physiological Anthropology, 33, 24. http://doi.org/10.1186/1880-6805-33-24

Norton, L. E., \& Layman, D. K. (2006). Leucine regulates translation initiation of protein synthesis in skeletal muscle after exercise. The Journal of Nutrition, 136(2), 533S-537S.

Norton, L. E., Layman, D. K., Bunpo, P., Anthony, T. G., Brana, D. V., \& Garlick, P. J. (2009). The leucine content of a complete meal directs peak activation but not duration of skeletal muscle protein synthesis and mammalian target of rapamycin signaling in rats. The Journal of Nutrition, 139(6), 1103-1109. http://doi.org/10.3945/jn.108.103853

Norton, L. E., Wilson, G. J., Layman, D. K., Moulton, C. J., \& Garlick, P. J. (2012). Leucine content of dietary proteins is a determinant of postprandial skeletal muscle protein synthesis in adult rats. Nutrition \& Metabolism, 9, 67. http://doi. org/10.1186/1743-7075-9-67

Pennings, B., Boirie, Y., Senden, J. M. G., Gijsen, A. P., Kuipers, H., \& van Loon, L. J. C. (2011). Whey protein stimulates postprandial muscle protein accretion more effectively than do casein and casein hydrolysate in older men. The American Journal of Clinical Nutrition, 93(5), 997-1005. http://doi.org/10.3945/ajcn.110.008102

Phillips, S. M., Tipton, K. D., Aarsland, A., Wolf, S. E., \& Wolfe, R. R. (1997). Mixed muscle protein synthesis and breakdown after resistance exercise in humans. The American Journal of Physiology, 273(1 Pt 1), E99-107.

Phillips, S. M., \& Van Loon, L. J. C. (2011). Dietary protein for athletes: From requirements to optimum adaptation. Journal of Sports Sciences, 29(sup1), S29-S38. http://doi.org/10.1080/02640414.2011.619204

Rasmussen, B. B., Tipton, K. D., Miller, S. L., Wolf, S. E., \& Wolfe, R. R. (2000). An oral essential amino acid-carbohydrate supplement enhances muscle protein anabolism after resistance exercise. Journal of Applied Physiology, 88(2), 386-392.

Schoenfeld, B. J. (2010). The Mechanisms of Muscle Hypertrophy and Their Application to Resistance Training: Journal of Strength and Conditioning Research, 24(10), 2857-2872. http://doi.org/10.1519/JSC.0b013e3181e840f3

Tang, J. E., Moore, D. R., Kujbida, G. W., Tarnopolsky, M. A., \& Phillips, S. M. (2009a). Ingestion of whey hydrolysate, casein, or soy protein isolate: effects on mixed muscle protein synthesis at rest and following resistance exercise in young men. Journal of applied physiology, 107(3), 987-992. http://doi.org/10.1152/japplphysiol.00076.2009

Tang, J. E., \& Phillips, S. M. (2009). Maximizing muscle protein anabolism: the role of protein quality. Current Opinion in Clinical Nutrition and Metabolic Care, 12(1), 66-71. http://doi.org/10.1097/MCO.0b013e32831cef75

Thibaudeau, C. (2007). The Black Book of Training Secrets: Enhanced Edition (Enhanced edition). Saint-Raymond, Quebec, Canada: Francois Lepine.

Tipton, K. D., Elliott, T. A., Cree, M. G., Aarsland, A. A., Sanford, A. P., \& Wolfe, R. R. (2007). Stimulation of net muscle protein synthesis by whey protein ingestion before and after exercise. American Journal of Physiology - Endocrinology and Metabolism, 292(1), E71-E76. http://doi.org/10.1152/ajpendo.00166.2006

Tipton, K. D., Elliott, T. A., Cree, M. G., Wolf, S. E., Sanford, A. P., \& Wolfe, R. R. (2004). Ingestion of casein and whey proteins result in muscle anabolism after resistance exercise. Medicine and Science in Sports and Exercise, 36(12), 2073-2081.

Tipton, K. D., Ferrando, A. A., Phillips, S. M., Doyle, D., \& Wolfe, R. R. (1999). Postexercise net protein synthesis in human muscle from orally administered amino acids. American Journal of Physiology - Endocrinology and Metabolism, 276(4), E628-E634.

Tipton, K. D., Rasmussen, B. B., Miller, S. L., Wolf, S. E., Owens-Stovall, S. K., Petrini, B. E., \& Wolfe, R. R. (2001). Timing of amino acid-carbohydrate ingestion alters anabolic response of muscle to resistance exercise. American Journal of Physiology - Endocrinology and Metabolism, 281(2), E197-E206.

West, D. W. D., Burd, N. A., Coffey, V. G., Baker, S. K., Burke, L. M., Hawley, J. A., .. Phillips, S. M. (2011). Rapid aminoacidemia enhances myofibrillar protein synthesis and anabolic intramuscular signaling responses after resistance exercise. The American Journal of Clinical Nutrition, 94(3), 795-803. http://doi.org/10.3945/ajcn.111.013722

Wilkinson, S. B., Phillips, S. M., Atherton, P. J., Patel, R., Yarasheski, K. E., Tarnopolsky, M. A., \& Rennie, M. J. (2008). Differential effects of resistance and endurance exercise in the fed state on signalling molecule phosphorylation and protein synthesis in human muscle. The Journal of Physiology, 586 (Pt 15), 3701-3717. http://doi.org/10.1113/jphysiol.2008.153916

Zatsiorsky, V., \& Kraemer, W. (2006). Science and Practice of Strength Training, Second Edition (2 edition). Champaign, IL: Human Kinetics. 